DE

M E D I C I N A

T R O P I C A L

$\mathrm{DE}$

SÃO PAULO

JOURNAL OF THE SÃO PAULO INSTITUTE OF TROPICAL MEDICINE

${ }^{1}$ Centro Universitário UnirG, Gurupi,

Tocantins, Brazil

2Universidade Federal de Goiás, Faculdade de Enfermagem, Goiânia, Goiás, Brazil

${ }^{3}$ Universidade Federal de Goiás, Instituto de Patologia Tropical e Saúde Pública, Goiânia, Goiás, Brazil

${ }^{4}$ Pontifícia Universidade Católica de Goiás, Departamento de Enfermagem, Goiânia, Goiás, Brazil

${ }^{5}$ Hospital de Doenças Tropicais de Araguaína, Serviço de Fígado e Hepatites, Araguaína, Tocantins, Brazil

${ }^{6}$ Hospital Naval Marcilio Dias, Clínica Médica, Rio de Janeiro, Rio de Janeiro, Brazil

${ }^{7}$ Pontifícia Universidade Católica de Goiás, Faculdade de Medicina, Goiânia, Goiás, Brazil

Correspondence to: Megmar Aparecida dos Santos Carneiro

Universidade Federal de Goiás, Instituto de Patologia Tropical e Saúde Pública, Prédio da Reitoria, Campus Samambaia, CEP 74001-970, Caixa Postal 131, Goiânia, GO, Brazil

Tel: +55 62 3209-6129

E-mail: megmar242@gmail.com

Received: 8 March 2018

Accepted: 15 June 2018

\section{Decline in hepatitis B and C prevalence among hemodialysis patients in Tocantins, Northern Brazil}

Valéria Maciel Cordeiro', Bruno César Teodoro Martins², Sheila Araujo Teles ${ }^{2}$, Regina Maria Bringel Martins ${ }^{3}$, Karla Prado de Souza Cruvinel ${ }^{4}$, Márcia Alves Dias de Matos $^{3}$, Jonio Arruda Luz ${ }^{5}$, Regiane Aparecida dos Santos Soares Barreto $^{2}$, Juliana Araujo Teles ${ }^{6}$, Nathália Carneiro Santos ${ }^{7}$, Karlla Antonieta Amorim Caetano², Megmar Aparecida dos Santos Carneiro ${ }^{3}$

\section{ABSTRACT}

Infection control measures have been responsible for a decline in the prevalence of hepatitis B virus (HBV) and hepatitis $\mathrm{C}$ virus (HCV) infections in hemodialysis patients. In Brazil, these measures have been in place since 1996. The aim of this study was to evaluate the current HBV and HCV epidemiology among hemodialysis patients in the State of Tocantins comparing them with those found 14 years ago. There was a significant decline in hepatitis B surface antigen ( $\mathrm{HBsAg}$ ) and anti-HCV prevalence from $4 \%$ and $13 \%$ in 2001 to $0.8 \%$ and $2.8 \%$ in $2014-2015$, respectively $(\mathrm{p}<0.05)$. Variables related to hemodialysis environment such as working shift and length of time on hemodialysis treatment were no longer associated to HCV and HBV exposure in 2014-2015. A high prevalence of self-reported hepatitis B vaccination was observed in both periods, but only $30 \%$ of the individuals showed serological profile of effective previous immunization, suggesting a low compliance with surveillance of hepatitis B immunization in hemodialysis centers. The significant decline in viral hepatitis $\mathrm{B}$ and $\mathrm{C}$ prevalence in hemodialysis patients in Tocantins underscores the importance of infection control measures, but the low frequency of protective serological profile after immunization against hepatitis B points to the need for greater vigilance of the patients' vaccination.

KEYWORDS: Epidemiology Viral hepatitis. Dialysis. Hepatitis B. Hepatitis C. Hemodialysis.

\section{INTRODUCTION}

Globally, about 257 million and 71 million people are chronically infected with hepatitis $\mathrm{B}$ virus (HBV) and hepatitis $\mathrm{C}$ virus $(\mathrm{HCV})$, respectively, and are at risk of developing cirrhosis and liver cancer. These infections have been the cause of 1.34 million deaths in $2015^{1}$.

Chronic Kidney Disease (CKD) is a public health problem worldwide. In Brazil, the incidence and prevalence of renal failure are increasing, the prognosis is still poor and treatment costs are high².

$\mathrm{HBV}$ and $\mathrm{HCV}$ are efficiently transmitted parenterally and these viruses have been a historical cause of comorbidities among hemodialysis patients. High prevalences of viral hepatitis $\mathrm{B}$ and $\mathrm{C}$ have been observed in hemodialysis centers worldwide. In general, these individuals are exposed to several risk factors for viral hepatitis $\mathrm{B}$ and $\mathrm{C}$, including blood transfusion, invasive medical procedures and sharing of infected patients' environments ${ }^{3,4}$. 
Unlike HCV, HBV infection can be prevented by vaccination. The HBV vaccine has been available and recommended for all hemodialysis patients since the $1980 \mathrm{~s}^{5}$. However, this virus remains a major public health problem, especially in developing countries with limited resources for hemodialysis patients, attended by health professionals who are less compliant with infection prevention and control measures ${ }^{6,7}$.

Studies show that the adoption of specific measures for infection control and prevention in hemodialysis centers contributes in a decisive way toward reducing the rates of $\mathrm{HBV}$ and $\mathrm{HCV}$ infections during hemodialysis ${ }^{8-10}$. In the USA, in the early 1970s, the incidence of HBV infection among chronic hemodialysis patients was $6.2 \%$, declining to $1 \%$ by 1980 following the adoption of control and prevention measures, and to $0.06 \%$ by 1999 following the inclusion of the hepatitis B vaccine ${ }^{8}$.

In Brazil, over the last 20 years, through public policies, infection control and prevention measures have been incorporated into the routine of hemodialysis centers. Monitoring of patients for viral hepatitis has become compulsory; the hepatitis B vaccine has become mandatory for all hemodialysis patients and health professionals; hepatitis B surface antigen (HBsAg) reagent patients are dialyzed in a segregated room and machine and by exclusive personnel ${ }^{11,12}$. However, information on the impact of these measures on the endemicity of hepatitis $\mathrm{B}$ and $\mathrm{C}$ in dialysis centers in the country is scarce ${ }^{13}$.

In 2001, this research group had the opportunity to investigate the epidemiology of hepatitis $\mathrm{B}$ and $\mathrm{C}$ in hemodialysis patients in the State of Tocantins, in the Northern region of the country. In the study period, there was only one hemodialysis center in the state, which served 100 patients. In that study, a prevalence of $16 \%$ for anti-HCV was observed. For hepatitis B, 45\% had been exposed to HBV (anti-HBc positive) and $4 \%$ were chronic carriers (HBsAg positive). Moreover, the study findings suggested that the hemodialysis environment played a role in viral dissemination ${ }^{14}$. The purpose of this study was to evaluate the impact of public policies for infection control and prevention in the epidemiology of viral hepatitis B and $\mathrm{C}$ in individuals undergoing hemodialysis in the State of Tocantins, located in the Northern region of Brazil.

\section{MATERIAL AND METHODS}

According to a population-based multicenter survey, the Northern region of Brazil has low HBV and HCV endemicity ${ }^{15}$. Tocantins is a State located in this region and occupies an area of $277,720,569 \mathrm{~km}^{2}$ being the newest State in Brazil (IBGE, 2017). It has a human development index (HDI) of 0.699 and a population of 1,497 million inhabitants. The main economic activities of the State are agriculture, cattle raising, extractivism and services.

In 2001, there was only one hemodialysis center located in the city of Gurupi, as previously described by Souza et $a l .{ }^{14}$. In 2014-2015, there were four centers of hemodialysis, which served 434 individuals in the three largest cities in the State: Palmas (2 centers, 265,409 inhabitants), Araguaina ( 1 center, 167,176 inhabitants) and Gurupi ( 1 center; 82,762 inhabitants). In these centers, all patients susceptible to viral hepatitis $\mathrm{B}$ and $\mathrm{C}$ were regularly monitored for $\mathrm{HBV}$ and $\mathrm{HCV}$ markers; HBsAg positive and anti-HCV positive patients were dialyzed in separate rooms and by exclusive nursing staff. Hemodialyzers used by patients positive for these markers were discarded after use and patients were vaccinated against hepatitis $B$.

This study was conducted in all working hemodialysis centers in the State of Tocantins. During the study period (October 2014 to February 2015), there were 434 chronic care patients being treated in the morning, afternoon and evening shifts. All patients aged 18 years or older on hemodialysis treatment for at least six months were included. Patients on acute hemodialysis were excluded.

A total of 425 individuals were eligible and 394 (92.7\%) participated in the study. All participants were interviewed on sociodemographic data, risk factors for viral hepatitis, and prior vaccination against hepatitis $B$.

After the interview and immediately before starting the hemodialysis treatment, $10 \mathrm{~mL}$ of blood were collected for the detection of HBV markers: HBsAg, anti-HBs and total anti-HBc by enzyme-linked immunosorbent assay using commercial kits (Hepanostika Ultra, Biomerieux and Biokit), as well as anti-HCV (Abbott Laboratories, Brazil).

Descriptive analysis was performed by frequencies, mean and standard deviation. Prevalences and Odds Ratios were calculated with $95 \%$ confidence intervals $(95 \% \mathrm{CI})$. The Chi-squared test $\left(\chi^{2}\right)$ or Fisher's exact tests were used to compare categoric variables, and Student's t-test for continuous variables. Values of $p<0.05$ were considered statistically significant. Data were compared to the ones collected by the research team 14 years ago ${ }^{12}$.

This study was approved by the Ethics Committees of the Fundação Pró-Rim, (Protocol No 054/2014) and Centro Universitário UnirG (protocol No 845.445).

\section{RESULTS}

The age of the patients was recorded. In 2001, the average age was 47.6 years (range: 13-82 years), while in 2015 it was 53.4 years (range: 18-90). There was a predominance of men in both study periods (62\% vs. 
$58.6 \%)$. The proportion of hemotransfused individuals decreased significantly from 2001 to 2014-2015 (96\% vs. $76.3 \%$ ). In 2001 , only $27 \%$ were in treatment for more than 36 months and this percentage reached $54.1 \%$ in 2014-2015. Since that time, a new shift was added for treatment and $28.2 \%$ of the hemodialysis patients underwent night shifts treatment in 2014-2015. Regarding vaccination against hepatitis B, in both periods, there was a large vaccination coverage, almost all patients received three or more doses of the vaccine (94\% vs. $97.2 \%$ ) (Table 1).

As shown in Figure 1, in 2001, the prevalence of HBsAg and anti-HBc was $4 \%$ and $45 \%$, respectively, declining to $0.8 \%$ and $35.6 \%$ in $2014-2015$ ( $p<0.05$ ) On the other hand, similar prevalence rates were found for anti-HBs isolated (27.9\% vs. $29.4 \%)$. Concerning anti-HCV, the prevalence was $13 \%$, dropping to $2.8 \%$ in 2014-2015 $(p<0.05)$.

As shown in Table 2, in 2001, individuals who underwent hemodialysis treatment during second shift had almost three-fold more chance to be exposed to the hepatitis B virus (OR 2.78; CI 95\%: 1.14-6.88) compared to those dialyzed in the first shift. Further length of time on hemodialysis (greater than three years) was a predictor of HCV infection (OR 19.2; CI 95\%: 2.17-69.4). In 20142015 , these variables were not associated with viral hepatitis markers.

\section{DISCUSSION}

Over the last three decades, the implementation of infection control and prevention measures in hemodialysis centers has been credited with an abrupt reduction in the endemicity of viral hepatitis B and $\mathrm{C}^{8}$. In Brazil, these measures were effectively implemented since 1996 through regulations from the Ministry of Health ${ }^{11,12}$, and certainly played a decisive role in reducing the prevalence of HBV and HCV infection in hemodialyzed patients in Tocantins ${ }^{14}$. In 2001, there was only one hemodialysis center in this State, which served 100 patients. Fourteen years later this number quadrupled and despite the increase in demand there was a decline in the endemicity of viral hepatitis B (HBsAg: $4 \%$ vs $0.8 \% ; \mathrm{p}<0.05$ ) and C (anti-HCV: $13 \%$ vs. $2.8 \% ; \mathrm{p}<0.0001)$.

Hemodialysis patients are routinely subjected to invasive procedures including punctures and extracorporeal circulation. In addition, they share the hemodialysis environment with many individuals with infectious diseases such as hepatitis B and C. Furthermore, they generally show impaired humoral and cellular immune response and consequently lower response to hepatitis B vaccine ${ }^{6}$. This conjunction of factors has been responsible for the strict association between viral exposure and hemodialysis treatment. In fact, in the prior study the dialysis environment

Table 1 - Characteristics of hemodialysis patients in Tocantins, Northern Brazil, 2001 and 2014-2015

\begin{tabular}{|c|c|c|c|c|c|}
\hline \multirow[t]{2}{*}{ Variable } & \multicolumn{2}{|c|}{$\begin{array}{c}2001 \\
(\mathrm{~N}=100)\end{array}$} & \multicolumn{2}{|c|}{$\begin{array}{c}2014-2015 \\
(\mathrm{~N}=394)\end{array}$} & \multirow[t]{2}{*}{$p$ value } \\
\hline & frequency & $\%$ & frequency & $\%$ & \\
\hline Age (mean; range) & $47.6(13-82)$ & & $53.4(18-90)$ & & $>0.05^{a}$ \\
\hline Male sex & 62 & 62.0 & 231 & 58.6 & $>0.05^{b}$ \\
\hline \multicolumn{6}{|c|}{ Previous blood transfusion* } \\
\hline No & 04 & 4.0 & 92 & 23.7 & \\
\hline Yes & 95 & 96.0 & 297 & 76.3 & $<0.001^{\mathrm{c}}$ \\
\hline \multicolumn{6}{|c|}{ Length of hemodialysis (months) } \\
\hline$<12$ & 29 & 29.0 & 40 & 10.2 & \\
\hline $12-36$ & 44 & 44.0 & 141 & 35.8 & $<0.001^{\mathrm{b}}$ \\
\hline$>36$ & 27 & 27.0 & 213 & 54.1 & \\
\hline \multicolumn{6}{|l|}{ Shift } \\
\hline Morning & 47 & 47.0 & 138 & 35.0 & \\
\hline Afternoon & 53 & 53.0 & 145 & 36.8 & $<0.001^{\mathrm{b}}$ \\
\hline Evening & 0 & - & 111 & 28.2 & \\
\hline \multicolumn{6}{|c|}{ Report of previous hepatitis $B$ vaccine } \\
\hline$<3$ doses & 06 & 6.0 & 11 & 2.8 & \\
\hline$\geq 3$ doses & 94 & 94.0 & 383 & 97.2 & $>0.05^{b}$ \\
\hline
\end{tabular}

*Missing value 2001: 01; missing values 2014-2015: 05. ${ }^{\text {aStudent's } t-t e s t ; ~}{ }^{b} \chi^{2}$ test; ' Fisher's exact test 


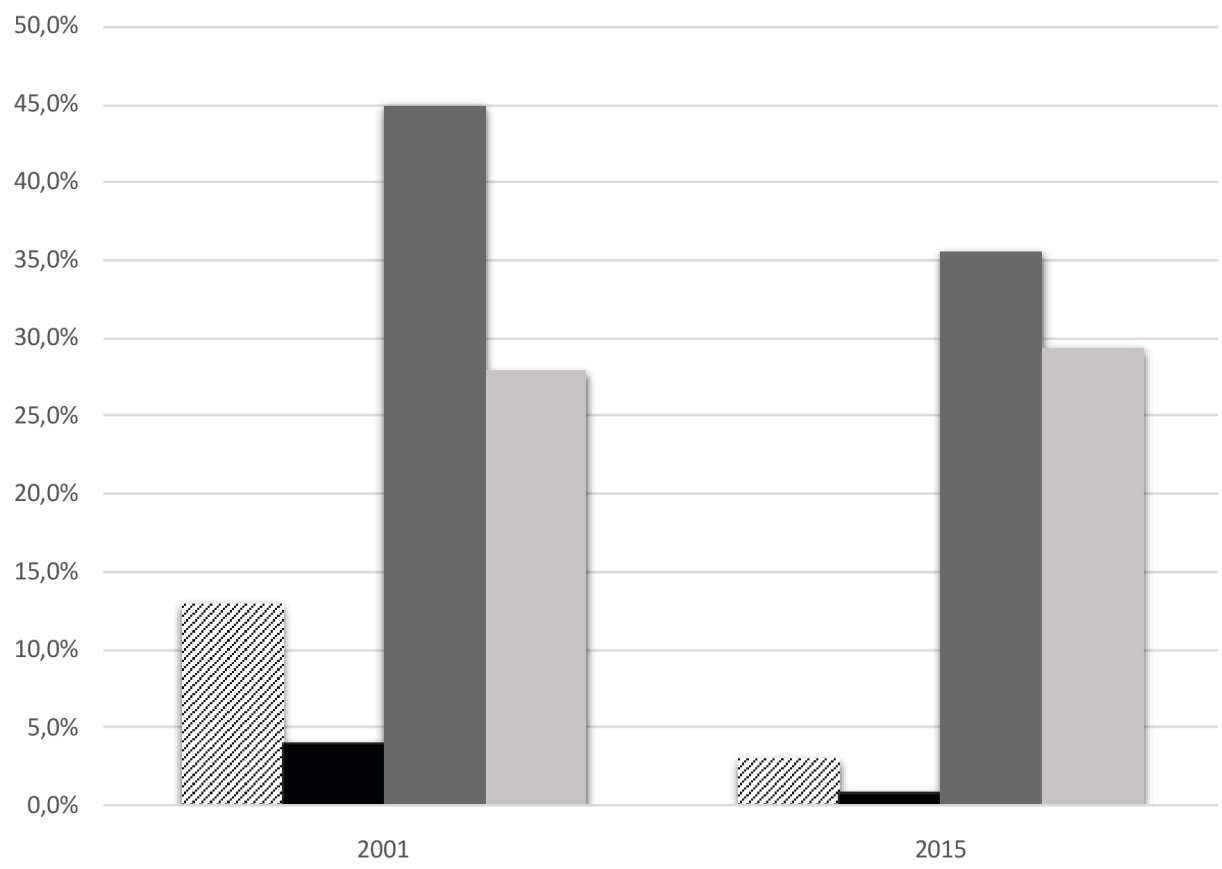

Figure 1 - Prevalence of HBV and HCV serological markers among hemodialysis patients in Tocantins, Northern Brazil, 2001 and 2014-2015; * $p<0.05$

Table 2 - Comparison of epidemiological data on hepatitis B and C between the years 2001 and 2014-2015 among hemodialysis patients in Tocantins, Northeastern Brazil

\begin{tabular}{|c|c|c|c|c|c|c|c|c|c|c|c|c|c|c|}
\hline \multirow{2}{*}{ Risk factor } & \multicolumn{7}{|c|}{2001} & \multicolumn{7}{|c|}{2015} \\
\hline & $n$ & $\mathrm{HBV}+$ & $(\%)$ & OR $(95 \% \mathrm{Cl})$ & $\mathrm{HCV}_{+}$ & $(\%)$ & OR $(95 \% \mathrm{Cl})$ & $\mathrm{n}$ & $\mathrm{HBV}+$ & $(\%)$ & OR $(95 \% \mathrm{Cl})$ & $\mathrm{HCV}+$ & $(\%)$ & OR $(95 \% \mathrm{Cl})$ \\
\hline \multicolumn{15}{|c|}{$\begin{array}{l}\text { Length of time on } \\
\text { hemodialysis }\end{array}$} \\
\hline$<1$ year & 29 & 14 & (44.3) & 1.0 & 1 & (3.4) & 1.0 & 40 & 10 & 25.0 & & 1 & 2.6 & 1.00 \\
\hline $1-3$ years & 44 & 17 & (38.6) & $\begin{array}{c}0.67 \\
(0.23-1.93)\end{array}$ & 4 & $(9.1)$ & $\begin{array}{c}2.8 \\
(0.27-69.4)\end{array}$ & 141 & 52 & 36.9 & $\begin{array}{c}1.75 \\
(0.79-3.87)\end{array}$ & 1 & 0.7 & $\begin{array}{c}0.28 \\
(0.02-4.52)\end{array}$ \\
\hline$>3$ years & 27 & 14 & (51.8) & $\begin{array}{c}1.15 \\
(0.35-3.76) \\
\end{array}$ & 11 & (40.7) & $\begin{array}{c}19.2 \\
(2.17-436.5) \\
\end{array}$ & 213 & 73 & 34.3 & $\begin{array}{c}1.56 \\
(0.72-3.38) \\
\end{array}$ & 9 & 4.2 & $\begin{array}{c}1.68 \\
(0.20-13.62) \\
\end{array}$ \\
\hline \multicolumn{15}{|l|}{ Shift $^{*}$} \\
\hline First & 47 & 15 & (31.9) & 1.0 & 9 & (19.1) & 1.0 & 138 & 48 & 34.8 & & 2 & 1.4 & 1.00 \\
\hline Second & 53 & 30 & (56.6) & $\begin{array}{c}2.78 \\
(1.14-6.88)\end{array}$ & 7 & (13.2) & $\begin{array}{c}0.64 \\
(0.19-2.12)\end{array}$ & 145 & 49 & 33.8 & $\begin{array}{c}0.96 \\
(0.59-1.56)\end{array}$ & 4 & 2.8 & $\begin{array}{c}1.93 \\
(0.358-10.7)\end{array}$ \\
\hline Third & - & - & & - & & & & 111 & 38 & 34.2 & $\begin{array}{c}0.98 \\
(0.58-1.65)\end{array}$ & 5 & 4.5 & $\begin{array}{c}3.24 \\
(0.61-17.02)\end{array}$ \\
\hline
\end{tabular}

n: number of patients; OR: odds ratio; $\mathrm{Cl}$ : confidence interval; * Considered for calculation, only patients dialyzed during first or second shift

probably played a role in viral dissemination ${ }^{14}$. In 2001, individuals who underwent evening shift treatment were 2.78 times more likely to be exposed to HBV, suggesting some failure to control infection between shifts. In relation to hepatitis $\mathrm{C}$, the chance of exposure was almost 20 times greater [Odds Ratio (OR): 19.25] after three years on hemodialysis.

On the other hand, this study was not able to identify these environmental variables as predictors of viral B and $\mathrm{C}$ exposure in 2014-2015. Most likely compliance with infection control measures contributed to reducing the chances of transmission in the dialysis environment. In addition, it should be pointed out that there is still controversy regarding the effectiveness of segregation of patients by room, machineand nursing personnel in the hemodialysis treatment of anti-HCV positive patients ${ }^{16}$. In Tocantins this strategy is used in all hemodialysis centers. Therefore, additional studies will be needed to analyze the role of this specific measure for the prevention of hepatitis $\mathrm{C}$ in the dialysis environment in Tocantins. 
In the past, blood transfusion was responsible for most cases of viral hepatitis B and C in hemodialysis centers. However, in countries that included the serological screening of these infections in their blood banks, cases of post-transfusional viral hepatitis have become rare. In Brazil, serological screening for HBsAg in blood banks started in 1989, and for anti-HBc and anti-HCV in $1993^{17}$. Therefore, although the majority (75\%) of hemodialysis patients investigated had reported previous blood transfusions, almost all of them were transfused after 1993 (data not shown). This measure may also have contributed to the decline in the endemicity of these infections in Tocantins dialysis centers.

Interestingly, although the vaccine coverage of hepatitis B in hemodialysis is high, the serological profile of previous immunization does not confirm the effective immunization status of these individuals. In both periods, only approximately $30 \%$ of hemodialysis patients had isolated positivity for anti-HBs. Unfortunately, we do not have information on the vaccine response shortly after the primary vaccination scheme, and on booster doses for non-responders, or for those who have not maintained post-vaccine anti-HBs protective titers. However, the low frequency of individuals with serological profile of HBV immunization is worrisome and suggests failure to monitor anti-HBs.

In fact, this discrepancy between vaccination reports and low frequency of isolated positivity for anti-HBs probably reflects the gradual decline in anti-HBs over the years. In healthy individuals, more than $90 \%$ respond to vaccination and show anti-HBs protective titers, remaining immune to $\mathrm{HBV}$ for at least 30 years, even with titers declining to undetectable levels, since immunological memory induces the formation of protective antibodies when there is an antigenic challenge ${ }^{18}$. On the other hand, in individuals with chronic kidney disease, these dynamic changes. In general, due to aging and immunosuppression, there is less vaccine response, and more frequent doses are required. In addition, anti-HBs titers decrease to non-protective levels more rapidly. For these individuals, unlike the healthy population, anti-HBs monitoring should be done regularly and booster doses should be performed when anti-HBs titers are less than $10 \mathrm{mUI} / \mathrm{mL}$, because of the risk of infection. In fact, outbreaks of viral hepatitis in the dialysis environment are not uncommon when infection control breaches occur ${ }^{3,4,7}$. Kliner et al. ${ }^{19}$ reported patient-to-patient transmission of HBV in a UK hemodialysis unit. According to these authors, the occurrence of this kind of event was attributed to non-compliance with infection control and prevention recommendations, which includes monitoring anti-HBs titers to indicate vaccination booster doses, when appropriate.
Some limitations of the study should be considered. The number of participants was insufficient to analyze potential risk factors for hepatitis $\mathrm{C}$, however, representing 92.7\% of the individuals undergoing chronic hemodialysis in the State of Tocantins. The vaccine card of the individuals undergoing hemodialysis was not verified, therefore, the information on the vaccination situation was collected through patient self-reports, which could be mistaken for memory bias.

This study provides valuable information on the epidemiology of viral hepatitis B and C at hemodialysis centers in Tocantins, Northern region of Brazil. Although the reductions in $\mathrm{HBsAg}$ and anti-HCV prevalence observed between 2001 and 2014-2015resulted from the efforts of managers and hemodialysis professionals to comply with infection control measures, the low proportion of individuals with a serological profile of prior immunization to hepatitis B suggests some weaknesses in monitoring the persistence of protective anti-HBs titers, a key strategy for the prevention of hepatitis B in the dialysis environment.

\section{AUTHORS' CONTRIBUTIONS}

The study design was provided by MASC and SAT; data collection was conducted by VMC, KPSC and JAL; data analysis was performed by SAT, KAAC and BCTM; laboratory tests were performed by JAT, NCS, MASC, RMBM and MADM. All authors participated in the interpretation of the data. SAT and MASC wrote the paper.

\section{ACKNOWLEDGMENTS}

The authors would like to thank Brian Ream for the English review. We thank all hemodialysis patients and staff of the hemodialysis centers of Tocantins, Brazil.

\section{REFERENCES}

1. World Health Organization. Global hepatitis report, 2017. Geneva: WHO; 2017. [cited 2018 June 16]. Available from: http://www. who.int/hepatitis/publications/global-hepatitis-report2017/en/

2. Sesso RC, Lopes AA, Thomé FS, Lugon JR, Watanabe Y, Santos DR. Chronic dialysis in Brazil: report of the Brazilian Dialysis Census, 2011. J Bras Nefrol. 2012;34: 272-7.

3. Fabrizi F, Dixit V, Messa P, Martin P. Transmission of hepatitis $B$ virus in dialysis units: a systematic review of reports on outbreaks. Int J Artif Organs. 2015;38:1-7.

4. Fabrizi F, Messa P. Transmission of hepatitis $C$ virus in dialysis units: a systematic review of reports on outbreaks. Int J Artif Organs. 2015;38:471-80. 
5. Desmyter J, Colaert J, De Groote G, Reynders M, ReerinkBrongers EE, Lelie PN, et al. Efficacy of heat-inactivated hepatitis B vaccine in haemodialysis patients and staff. Doubleblind placebo-controlled trial. Lancet. 1983;2:1323-8.

6. Bernieh B. Viral hepatitis in hemodialysis: an update. J Transl Int Med. 2015;3:93-105.

7. Duong CM, McLaws ML. An investigation of an outbreak of hepatitis $\mathrm{C}$ virus infections in a low-resourced hemodialysis unit in Vietnam. Am J Infect Control. 2016;44:560-6.

8. Recommendations for preventing transmission of infections among chronic hemodialysis patients. MMWR Recomm Rep. 2001;50:1-43.

9. Finelli L, Miller JT, Tokars JI. Alter MJ, Arduino MJ. National surveillance of dialysis-associated diseases in the United States, 2002. Semin Dial. 2005;18:52-61.

10. Sauné K, Kamar N, Miédougé M, Weclawiak H, Dubois M, Izopet $\mathrm{J}$, et al. Decreased prevalence and incidence of HCV markers in haemodialysis units: a multicentric French survey. Nephrol Dial Transplant. 2011;26:2309-16.

11. Brasil. Ministério da Saúde. Gabinete do Ministro. Portaria n 2.042 , de 11 de outrubro de 1996. Diário Oficial da União, Brasília, 14 Out 1996.

12. Brasil. Ministério da Saúde. Agência Nacional de Vigilância Sanitária. Resolução da Diretoria Colegiada - RDC n ${ }^{\circ}$ 154, de 15 de junho de 2004. Diário Oficial da União, Brasília, 17 Jun 2004.
13. Carneiro MA, Teles SA, Dias MA, Ferreira RC, Naghettine AV, Silva AS, et al. Decline of hepatitis C infection in hemodialysis patients in Central Brazil: a ten years of surveillance. Mem Inst Oswaldo Cruz. 2005;100:345-9.

14. Souza KP, Luz JA, Teles SA, Carneiro MA, Oliveira LA, Gomes AS, et al. Hepatitis B and C in the hemodialysis unit of Tocantins, Brazil: serological and molecular profiles. Mem Inst Oswaldo Cruz. 2003;98:599-603.

15. Pereira LM, Ximenes RA, Moreira RC. Estudo de prevalência de base populacional das infecções pelos vírus das hepatites A, B e C nas capitais do Brasil. Recife: Universidade Federal de Pernambuco; 2010.

16. Amin Elzorkany KM, Zahran A. Hepatitis C virus status in hemodialysis patients in Menoufia Government, Egypt, five years apart: do we have any improvement? Saudi J Kidney Dis Transpl. 2017;28:1126-32.

17. Brasil. Ministério da Saúde. Gabinete do Ministro. Portaria n ${ }^{\circ} 1.376$, de 19 de novembro de 1993. Brasília: Diário Oficial da União, Brasília, 2 Dez. 1993.

18. Bruce MG, Bruden D, Hurlburt D, Zanis C, Thompson G, Rea L, et al. Antibody levels and protection after hepatitis $\mathrm{B}$ vaccine: results of a 30-year follow-up study and response to a booster dose. J Infect Dis. 2016;214:16-22.

19. Kliner M, Dardamissis E, Abraham KA, Sen R, Lal P, Pandya B, et al. Identification, investigation and management of patientto-patient hepatitis B transmission within an inpatient renal ward in North West England. Clin Kidney J. 2015;8:102-6. 